Journal Of Agriculture and Social Research (JASR) Vol. 8, No.1, 2008

\title{
IMPACT OF ETHNIC CONFLICTS ON LIVESTOCK PRODUCTION IN AFRICA: THE CASE OF THE NORTHERN REGION OF GHANA
}

\author{
ADDAH, W. AND ZEZEBI, N
}

\begin{abstract}
Rampant ethnic conflicts and civil wars in the northern parts of most African countries have destroyed and continue to destroy the economies of such regions which are usually pastoral and dependent on livestock. This has resulted in a vicious cycle of poverty and under-development among the people of such regions. This study assessed the effects of the guinea fowl war (19941995) on household livestock holding sizes and other support services of the livestock industry in the northern region of Ghana. Before the conflict, every household owned livestock however during the conflict most feed and water resources were poisoned or destroyed, livestock stolen or indiscriminately killed or starved to death. After the conflict had subsided, 23\%, 16\%, 12\% and $21 \%$ of households could not own any cattle, sheep, goats and poultry respectively. Commercial household holding sizes (>100) of cattle also declined from $12 \%$ before the conflict to $0 \%$ after the conflict and even a decade after the conflict had ended, it only increased by $0.7 \%$ per annum. The cumulative percentages of households who still kept more than 50 sheep, goats and poultry after the conflict also declined after the conflict. The conflict also destroyed other allied livestock support services and infrastructure culminating into sporadic outbreaks of livestock diseases. A postconflict recovery assessment indicates that only 23\% of households had some surviving livestock left after the conflict that could be used for breeding to restock their farms. A relief package worth US\$ 650,000 was implemented by the Government of Ghana through the MoFA to help ameliorate the livestock sector in the region but a decade after the conflict, most farmers have not yet fully recovered from the losses they suffered; household holding sizes have since remained small and subsistent. The effect of the conflict on livestock production was particularly severe because livestock production in northern Ghana is customarily the domain of males who unfortunately were the main victims of the conflict.
\end{abstract}

Key words: conflict, guinea fowl war, livestock, recovery rate

\section{INTRODUCTION}

Ethnic-based conflicts in Africa south of the Sahara such as the Biafra war in Nigeria, the civil war in Liberia and Sierra Leone, the conflict of the great lake region (Burundi, Democratic Republic of Congo, Rwanda, Tanzania, and Uganda), the Ethiopian-Eritrean war, the civil wars in Sudan and Cote d' Ivoire have rolled back development in Africa made in colonial and post colonial eras to over 100 years in history (Kusimi et al., 2006). According to the FAO (2004), conflicts cost Africa over $\$ 120$ billion worth of agricultural production during the last third of the twentieth century resulting in 198,000,000 people suffering from food insecurity.

Causes of conflict in developing countries are varied but often consistent; they include ethnic rivalries, unfair allocation and control of natural resources (land, water, forest, mineral resources and oil), an imbalance in the distribution of the national cake, colonial and post-colonial land tenure arrangements and selfish political manipulations (Messer and Cohen, 2004; Kusimi et al, 2006; Bacho and Abdul-Kadir, 2007).

The relationship between conflicts and livestock production in Africa is complex and interwoven; conflict depopulates livestock numbers, on the other hand, livestock production systems, especially ownership and management systems, cause conflicts. In the past, analyst of conflicts in Africa have argued that conflicts were mainly caused by struggle for control over commodities such as oil and diamond but recent studies of conflictology in the region suggest a 
strong correlation between conflict and livestock especially in pastoral regions that have the potential for livestock production (Abubakar, 2004; Bacho and Abdul-Kadir, 2007). Struggles for access and control of grazing lands have caused several conflicts in Africa. Between 1997 and 2003 there have been 7 conflicts in Nigeria caused by disputes over grazing lands (Bacho and AbdulKadir, 2007).

The northern region of Ghana is traditionally described as the food basket of the nation; $70 \%$ of its land has the potential for livestock production, hence $77 \%, 55 \%$, and $45 \%$ of the nation's cattle, small ruminants, and pigs and poultry respectively are produced from the region with farmers in the region deriving as much as $42.6 \%$ of their income from the sale of livestock alone (Karbo and Bruce, 2000). The dichotomy between these potential economic resources and escalating poverty levels in the region probably accounts for 22 conflicts that occurred between 1980 and 2002, notable among which was the 1994-1995 ethnic conflict which was unprecedented in the independent history of Ghana (Jösson, 2007). The conflict which was sparked off by a dispute over the price of a black guinea fowl between a Nanumba tribesman and a Komkomba tribesman at a livestock market at Nakpali in the Nanumba North district on $31^{\text {st }}$ January, 1994 later engulfed 3 other ethnic groups and 6 administrative districts resulting in a total of 20,000 deaths. According to the World Bank's definition of war, any conflict that results in more than 1,000 combat-related deaths is classified as a war. The terms "war" and "conflict" have therefore been used interchangeably in this study.

Most conflicts in the northern region of Ghana are usually triggered off by simple episodes but end up with a lot of great consequences in terms of loss of human lives and properties as well as other resources. It is often implied that the wars were fought over such trivial items as mangoes, local drinks (pito), guinea fowls and cattle; two of such important wars in the history of the northern region of Ghana have livestock connotations: the cow war (1940) and the guinea fowl war (19941995). This study was therefore conducted to assess the effect of the guinea fowl war (1994 -1995) on livestock production in 3 of the 7 affected districts.

\section{MATERIALS AND METHODS}

The conflict affected 7 administrative districts of the Northern region; Yendi, Saboba-Chereponi, East Gonja, Nanumba, Zabzugu-Tatale, Gushiegu-Karaga and Tamale (see Figure 1) but its intensity was most severest in 3 districts; Yendi, Saboba-Chereponi and East Gonja (Linde and Naylor, 1998; Mahama, 2003). These 3 districts alone respectively produce $29 \%, 28 \%, 23 \%$ and $23 \%$ of the region's cattle, sheep, goats and poultry (SPLP, 1996) and therefore constituted the study areas for this work. Five communities each were purposively sampled from the 3 affected districts based on the severity of the conflict. Semi-structured questionnaires were used to interview 6 randomly selected household heads in each community. A total of ninety (90) household heads made up of 87 males and 3 females were interviewed. The questions in the questionnaire were segmented into 3 periods; before (1993), after (1996) and a decade after (2006), the conflict occurred. Respondents provided answers to questions in the questionnaire based on memory recall while the extent of physical damage was also noticed by observing remnants of the conflict. Secondary data was also sourced from the Ministry of Food and Agriculture (MoFA) of Ghana and other reports of committees that were commissioned to investigate the causes of the conflict. The data collected was analyzed by SPSS (Statistical Package for Social Sciences, version 11.0).




Figure 1 Map of Northern Ghana (Courtesy: Kusimi et al., 2006)

\section{RESULTS AND DISCUSSION}

Socio-demographic characteristics

The active workforce (31- 40 years) represented $40 \%$ while those of school-going age (10-30 years) and the aged (51 - >60 years) cumulatively constituted $60 \%$ of the population. During the conflict most young men and women fled to southern Ghana and other regions leaving the aged and children behind. Ten years later, most of them have not yet returned. It is estimated that about 200, 000 people were displaced internally by the conflict (Bacho and Abdul-Kadir, 2007; Mahama, 2003; Linde and Naylor, 1998).

The average illiteracy level in the 3 districts in the present study was $63 \%$ with only $\mathbf{4 . 4 \%}$ having tertiary education. Illiteracy rates in Ghana tend to be worse in rural areas with levels reaching $92 \%$ for women and $70 \%$ for men in the northern region compared to a national average of $64.2 \%$ (GPRS, 2003). This is particularly significant in the Komkombadominated district of the Saboba-Chereponi where $93.3 \%$ of people live in rural areas (NHPC, 2000). 


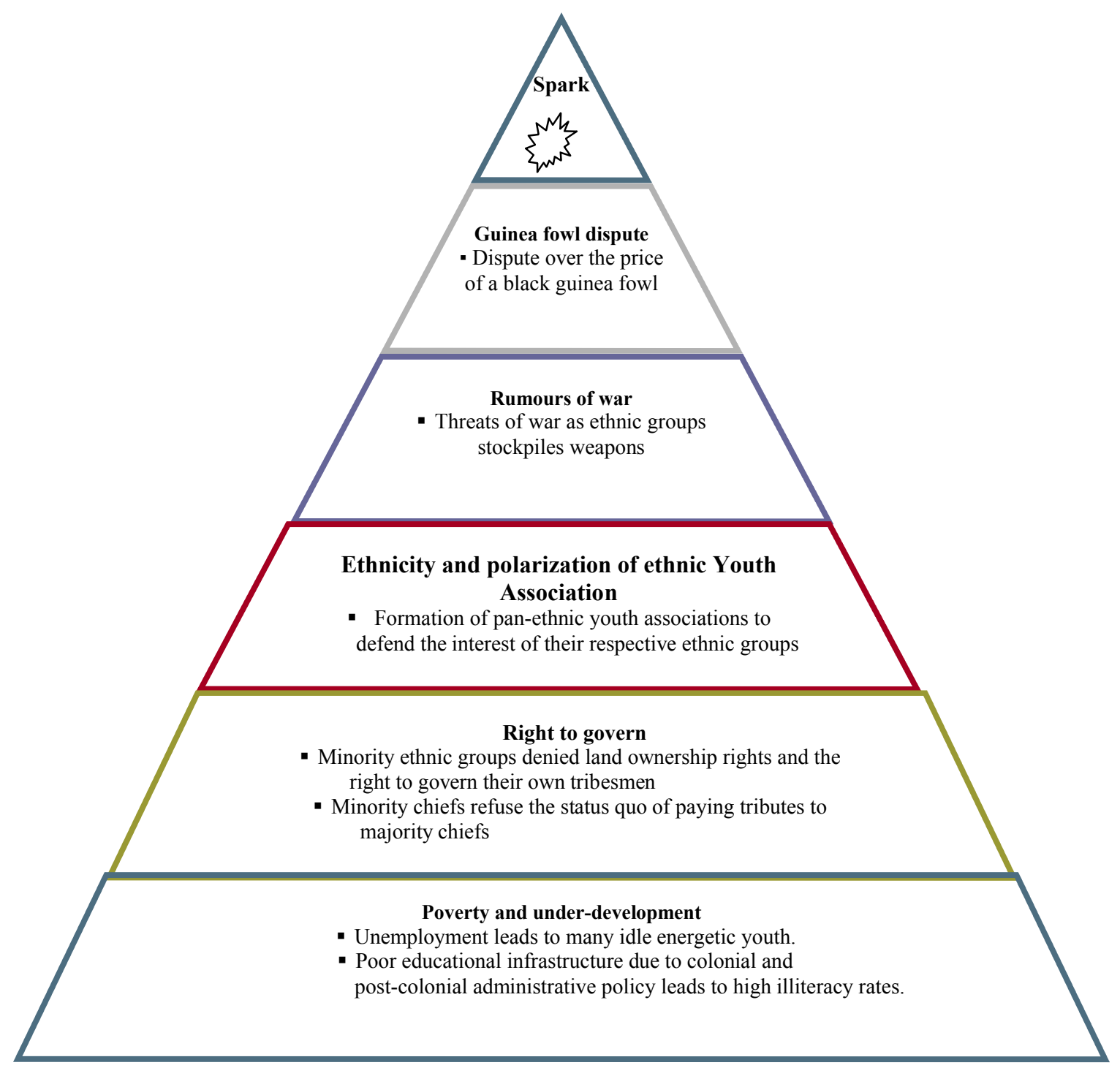

Figure 2 Pyramid of causes of the guinea fowl war (1994 -1995). Source: Linde and Naylor (1998); Jösson (2007)

It has been argued that the low level of education in the region partly accounts for its vulnerability to violence and conflicts (Jösson, 2007). Seven out of every ten persons in the northern region live below the poverty line of $\$ 1$ per capita per day (GPRS, 2003). Poverty has therefore reduced the value of human life. There were reports that during the conflict, some men did not know what they were fighting for while others were paid a mere sum of $\notin 100,000(\$ 10.4)$ per day to fight (Jösson, 2007). Poverty and underdevelopment have therefore been underlined as the fundamental causes of conflicts in the northern region of Ghana (Linde and Naylor, 1998; Jösson, 2007) (see Figure 2). The greatest threat to the achievement of the first Millennium Development Goal (MDG) of eradicating extreme poverty and hunger by halving the proportion of people living on less than US $\$ 1$ per day and those who suffer from extreme hunger, in Africa could be the rampant incidence of conflicts. 


\section{Impact of the conflict on Cattle production}

The herd sizes of households before, after and a decade after the conflict are shown in Table 1. Every household in the study area owned cattle in the period before the conflict. According to Avornyo et al. (2007), except for the very poor farmer, almost every household in the northern region of Ghana owns some livestock. Ownership of cattle in the region is indicative of financial and social status in the community and every household tries to keep some (Otchere et al., 2007; Avornyo et al., 2007). The percentage of households keeping smaller herds of cattle (1-20) increased from 30\% in 1993 to $38 \%$ in 1996 and then declined slightly to $33 \%$ in 2006 . Recent studies of cattle management in the Saboba-Chereponi district(one of the study districts) confirm that holding sizes of farmers in the district have changed in favour of smaller herds with majority (47\%) of them keeping 11-20 cattle (Otchere et al., 2007). The cumulative percentage of commercial households keeping 81 - >100 cattle in the present study also declined from $24 \%$ in 1993 to as low as 4\% in 1996 indicating a decline of 4\% per annum. It can be inferred that the conflict has changed the scale of production of most farmers from commercial to subsistent. Before the conflict in 1993, 12\% of households owned more than 100 cattle but immediately after it ended in 1996, no farmer could own more than 100 cattle again. A decade after the conflict (2006), 23\% of households could not still boast of any cattle. According to Mahama (2003), the guinea fowl war resulted in the loss of 2,130 and 20,000 cattle in the Yendi and the Nanumba districts alone respectively. Data from the MoFA in the northern region similarly indicates that $11.9 \%$ of cattle in the three study locations were lost to the guinea fowl war (SPLP, 1996). As also illustrated in Figure 3 the population of cattle declined from 406,051 in 1993 to 357,557 by the end of 1995 when the conflict had subsided. Hence an analysis of the price differential of cattle shows that the average price of an adult cattle also increased from $\notin 150,000(\$ 150)$ in 1993 before the conflict to $\$ 350,000(\$ 219)$ after the conflict in 1996.

The effects of losses of cattle on the farmer goes beyond those of inadequate supply of meat, milk, manure and income from the sale of animals and their products; more than $30 \%$ of the total land area of the northern region is ploughed by bullocks with households who own bullocks, ploughing 60\% more land area than those without bullocks (Karbo and Bruce, 2000). The loss of cattle coupled with the exodus of able-bodied youth to urban centres in southern Ghana and neighbouring Togo therefore resulted in farmers not being able to increase their farm sizes due to inadequate household labour, subsequently leading to low agricultural productivity and hence a national food security crisis in 1996. Hoe-dependent methods of farming and high school drop-out rates also became common in the area.

During conflicts, cattle become the target animals because they are worth several other livestock and are easily rustled away compared to small ruminants. In the plateau state of Nigeria, an ethno-religious conflict that broke off on $7^{\text {th }}$ September, 2001 resulted in the killing of Fulani herders and their cattle and the rustling away of large numbers of cattle (Abubakar, 2004). Cattle rustling have also been the common cause of conflicts in the Kidepo valley of Uganda where Karamoja and Dodos rustlers even sometimes cross borders into Kenya and Southern Sudan to steal cattle (Brock-Utne, 2001).

Table 1 Effects of the conflict on household herd sizes of cattle

\begin{tabular}{llll}
\hline Herd size & $\begin{array}{l}\text { Before the conflict } \\
\text { (\% of HHs) }\end{array}$ & $\begin{array}{l}\text { After the conflict } \\
\text { (\% of HHs) }\end{array}$ & $\begin{array}{l}\text { A decade after the conflict } \\
\text { (\% of HHs) }\end{array}$ \\
\hline $1-20$ & 30 & 38 & 33 \\
$21-40$ & 19 & 23 & 29
\end{tabular}


Journal Of Agriculture and Social Research (JASR) Vol. 8, No.1, 2008

\begin{tabular}{llll}
$41-60$ & 13 & 8 & 7 \\
$61-80$ & 13 & 3 & 4 \\
$81-100$ & 12 & 4 & 7 \\
$100+$ & 12 & 0 & 7 \\
NIL & 0 & 23 & 13 \\
\hline Total & 100 & 100 & 100 \\
\hline
\end{tabular}

HHs: Households

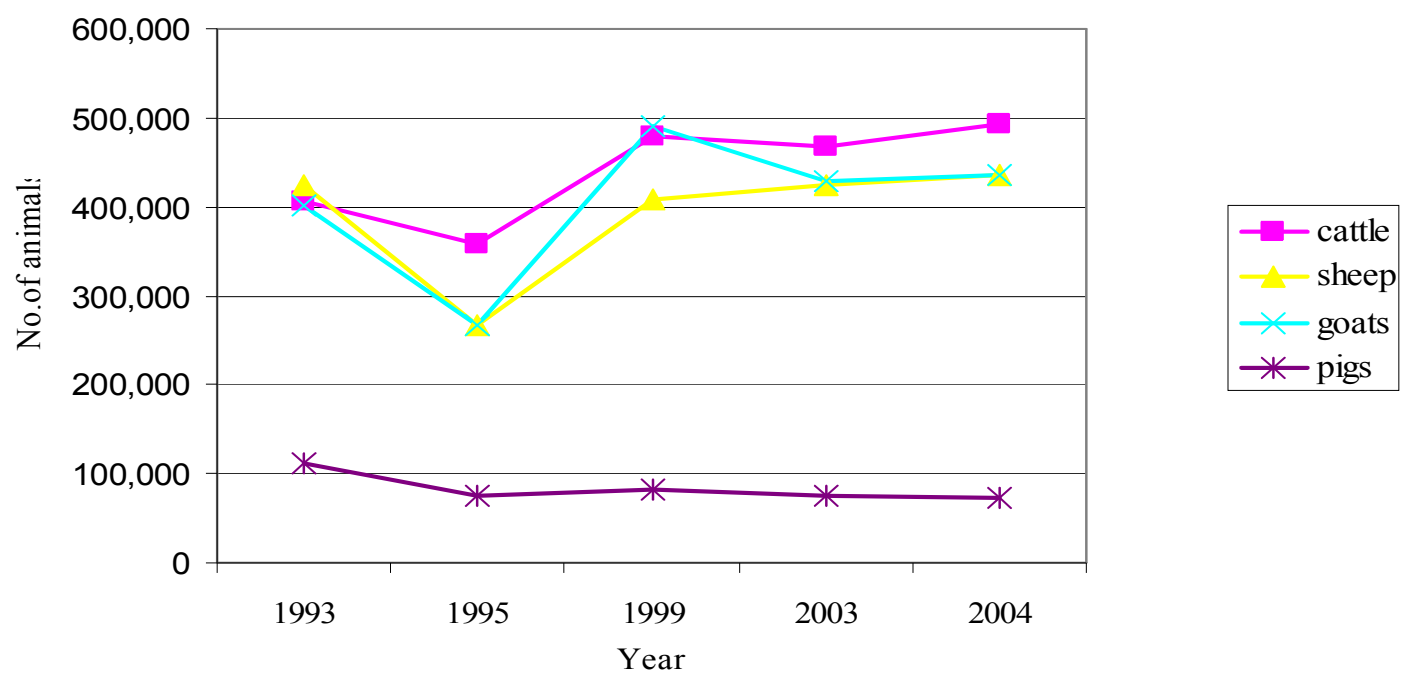

Figure 3 Livestock population of the Northern region of Ghana (1993- 2004) Source: SPLP (1996) 


\section{The impact of the conflict on small ruminants and poultry production}

As shown in Figure 3 and Table 2, the effects of the war on sheep and goats production followed a similar trend as those of cattle. After the conflict, no farmer could own more than 60 sheep and even in 2006, only one farmer kept more than 60 sheep. Sheep and goats were indiscriminately killed and carried away to prepare meals for battle warriors. The percentage of households who were engaged in small-scale (1-10) sheep and goat production in 1993 were $24.4 \%$ and $17 \%$ respectively. By the end of the conflict in 1996, this increased to $57.8 \%$ and $49 \%$ respectively indicating a more than $100 \%$ rise after the war. Even though all the respondents kept sheep and goats before the war, after the war(1996), 16.7\% and 12.2\% could not own any sheep and goats respectively again. It is estimated that the Yendi district alone which was the core of the war lost 1,260 sheep and 2,462 goats to the war (Mahama, 2003). The high percentage of households (48.9\%) keeping smaller flock of sheep(11-20) is consistent with other studies in the area after the conflict; Otchere et al.(1997) reported an average flock size of 20 sheep per capita in the Saboba-Chereponi district and as recent as 2007, similar studies in the conflict-ravaged districts still indicated that $37 \%$ of households owned 1-10 sheep with no farmer owning more than 50 sheep while only $1 \%$ owned more than 50 goats(Avornyo et al., 2007). The war therefore appears to have permanently destroyed the livestock industry which is the source of livelihoods of most households in the region.

Small ruminants serve as a short-term cash reserve. Income from the sale of goats bridges an important gap between the lean and harvest seasons. It is therefore the most sold animal to buy food in the lean season with an average of 6 goats compared to 5 sheep, sold annually in the northern region (Karbo and Bruce, 2000). Data from the Livestock Production and Information Unit of the MoFA on the slaughter and consumption of sheep and goats between 1986/90 and 1995 shows a decline of 18,551 to 15,051 and 33,393 to 25,907 respectively. This low level of meat consumption coupled with the food insecurity in the region in 1996 resulted in $60 \%$ of children in the war zone becoming malnourished (Linde and Naylor, 1998).

Table 2 Effects of the conflict on household holding size of small ruminants

\begin{tabular}{|c|c|c|c|c|c|c|}
\hline \multirow[b]{2}{*}{$\begin{array}{l}\text { Hold } \\
\text { size }\end{array}$} & \multicolumn{3}{|l|}{ Sheep } & \multicolumn{3}{|l|}{ Goats } \\
\hline & $\begin{array}{l}\text { Before the } \\
\text { conflict } \\
\text { (\% of } \mathrm{HHs})\end{array}$ & $\begin{array}{l}\text { After the } \\
\text { conflict } \\
\text { ( } \% \text { of } \mathrm{HHs})\end{array}$ & $\begin{array}{l}\text { A decade } \\
\text { after the } \\
\text { conflict } \\
\text { ( } \% \text { of } \mathrm{HHs})\end{array}$ & $\begin{array}{l}\text { Before the } \\
\text { conflict } \\
\text { (\% of } \mathrm{HHs} \text { ) }\end{array}$ & $\begin{array}{l}\text { After the } \\
\text { conflict } \\
(\% \text { of } \mathrm{HHs})\end{array}$ & $\begin{array}{l}\text { A decade } \\
\text { after the } \\
\text { conflict } \\
(\% \text { of } \mathrm{HHs})\end{array}$ \\
\hline $1-10$ & 24.4 & 57.8 & 37.8 & 17 & 49 & 33 \\
\hline $11-20$ & 48.9 & 13.3 & 28.9 & 46 & 21 & 17 \\
\hline $21-30$ & 6.7 & 4.4 & 7.8 & 16 & 7 & 18 \\
\hline $31-40$ & 7.8 & 3.3 & 6.7 & 8 & 6 & 10 \\
\hline $41-50$ & 5.6 & 3.3 & 5.5 & 8 & 4 & 10 \\
\hline $51-60$ & 5.6 & 1.1 & 3.3 & 7 & 0 & 8 \\
\hline $60+$ & 1.1 & 0 & 1.1 & 0 & 0 & 0 \\
\hline Nil & 0 & 16.7 & 11.1 & 0 & 12.2 & 4.4 \\
\hline Total & 100 & 100 & 100 & 100 & 100 & 100 \\
\hline
\end{tabular}

HHs: Households

Even though the conflict did not directly affect poultry as it did to cattle and small ruminants, most households lost almost all theirs birds to Newcastle (33\%), coccidiosis $(27.8 \%)$, fowl pox $(22 \%)$ and other unknown factors (21\%) immediately after the conflict. In 1993, a cumulative $20 \%$ of households were keeping 1-20 birds while 36\% were keeping 41-70 birds. By 1996, those keeping 1-20 birds had increased to 59\% while those keeping 41-70 birds respectively decreased to $8 \%$. 
Small-scale rural poultry production in the northern region of Ghana is important because it promotes the consumption of meat and eggs that helps to complement the protein levels of lowprotein staple diets and improve the nutrition of children thereby reducing malnutrition and its associated problems.

\section{Impact of the conflict on management systems and the incidence of diseases}

Many farmers shifted from the traditional extensive system of management in the period before the conflict to the semi-intensive and intensive systems of management while those who still practised the extensive system occasionally provided supplementary feed and medication in an effort to secure their remaining animals after the conflict. The percentage of households who practised the extensive system dropped from $70 \%$ before the conflict to $57 \%$ in the post-conflict era. Similarly those practising the semi-intensive and intensive systems of management increased from $22 \%$ and $7 \%$ to $31 \%$ and $12 \%$ respectively. The various avenues of losses during the conflict included stealing/rustling $(34 \%)$, starvation $(14 \%)$, poisoning $(24 \%)$, indiscriminate killing $(24 \%)$ and diseases and pests (4\%). The extensive system of management rendered animals vulnerable to stealing, rustling and disease outbreaks. The incidence of anthrax, pneumonia, Newcastle and strange diseases increased after the conflict. This could be attributed to the disruption of the MoFA's surveillance on disease outbreaks. In pursuit of the enemy, rivers, streams, ponds and other water bodies were also poisoned or destroyed while available feed resources were burnt.

\section{Impact on livestock services, infrastructure, agricultural machinery, farm labour and social services}

The conflict caused veterinary and agricultural extension staff of the MoFA at all the 7 districts engulfed in the conflict to flee for safety. This affected the MoFA's planned programmes on surveillance and curbing of livestock disease outbreaks. Three Farmers Service Centres were destroyed while 2 were looted. The Agricultural Development Bank that extends about $60 \%$ of its total loans to farmers also suspended its loans scheme and closed down its offices in the area. Other international organizations involved in the provision of livestock extension services and microcredit such as the German Technical Development Agency (GTZ), the Catholic Relief Services (CRS), the United Nations Children Fund (UNICEF) and the Assemblies of God Relief and Development Service (AGREDS) also withdrew their services. The absence of these services resulted in the outbreak of several livestock diseases and low crop yields leading to high livestock mortalities and general food shortage between 1995 and 1997.

A major livestock and yam market at Nakpali, where the conflict started, was empty for more than 6 months after the conflict. A total of 2,500 teachers and 746 schools were affected while 65,384 students were displaced (Linde and Naylor, 1998). As illustrated in Figure 4, men and boys were the major victims of the conflict. The high causalities among them reduced the labour force available for livestock production activities. This is particularly significant because ownership of cattle, sheep and goats by women, especially of child-bearing age is customarily prohibited among the Dagomba, Komkomba and Chokosi ethnic groups (Otchere et al., 1997; Karbo et al., 2000). The devastation of the livestock industry in the northern region by the guinea fowl war did not only affect livestock farmers but other auxiliary livestock industries; butchers, meat processors, middlemen, and hide-makers also lost their jobs 


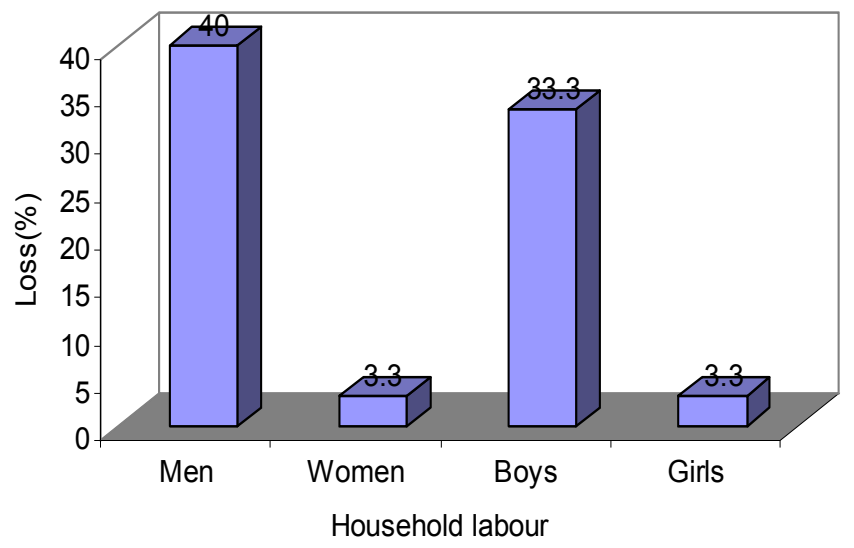

Figure 4 Losses in household labour available for livestock production

About 7\% of households lost their tractors and implements. The destruction of such machinery suggests a reduction not only in their capacity to restart and expand their livestock populations but also other agricultural activities in general. Thirty six percent $(36 \%)$ of households lost their hens coops, $31 \%$ lost their pens for small ruminants while $51 \%$ had their cattle kraals vandalized and the cattle rustled away.

\section{Restocking and Recovery}

The conflict destroyed the breeding stock of most households. Only 23\% of households had some surviving animals that could be used for breeding to replenish their farms after the conflict. Most households (45\%) therefore bought their animals from the open market. Those who received support directly from the Government through the MoFA were rather few (3\%) while others relied on family members and friends $(21 \%)$ to start all over again. Many people traveled out side the region, worked for money and returned to commence their farming activities. This group of people was able to raised substantial capital to quickly restart breeding programmes to replenish their lost stock. The support that came from NGOs for livestock production benefited only $8 \%$ of households.

The recovery rate of poultry farmers was better than those of cattle and small ruminants because they can easily be multiplied within a short period of time; by 2006, the percentage of households keeping birds in the range of $1-20$ decreased from 59\% in 1996 to $27 \%$ while those in the commercial range (41-70) increased from $8 \%$ in 1996 to $13 \%$ in 2006 . The annual recovery rate of small ruminants was higher than those keeping cattle. The rate for those who kept sheep on a small scale (1-10) between 1996 and 2006 was 2\% compared to $0.45 \%$ for households keeping 120 cattle within the same periods. Following a needs-assessment by the MoFA, a relief package valued at $\$ 650,000$ was implemented to provide relief for victims and internally displaced persons. The package included mass livestock vaccination, quarantine of strayed animals and training programmes on bullock ploughing. It also included distribution of hoes, cutlasses, power tillers, provision of tractor services and training of farmers on seed multiplication. The MoFA also introduced "bull-lending" where bulls of good breeding traits were lent among households to improve their herds (MoFA, 1994). The AGREDS similarly introduced a system whereby a cow is given to a Komkomba and after it has calved, it is taken away and given to a Nanumba while the Komkomba retains the weaned calf. When the cow calves again the Nanumba retains the calf and return it to another Komkomba in that order (Ansah et al., 2006). Despite all these interventions, a decade after the conflict (2006), most farmers are yet to fully recover from the impact of the conflict 


\section{CONCLUSION}

Livestock have been the cause and also continue to suffer the effects most conflicts in Africa. The guinea fowl war has significantly devastated and retrogressed agricultural development in general and livestock production in particular. The results of this study suggest that most livestock farmers in the 1994/5 conflict zone have not fully recovered from losses due to the conflict even a decade after the conflict ended. The war thus appears to have significantly threatened the region's lead role in supplying most of the nation's meat requirements

No matter the amount of any relief, the devastation caused by conflicts are usually very difficult to simply be paid-off by relief, as people's cultures and the natural bond that exist between them and their properties cannot simply be replaced by any kind of relief. The value of livestock breeds bred over many years to suit a particular environment cannot also simply be replaced by the introduction of any kind of new breeds.

Conflicts destroy the normal food and livestock production chain leading to food and nutrition insecurity, social mistrust, animosity and also scare away foreign direct investment ultimately entrenching poverty. Regions that have thus experienced protracted conflicts continue to be counted among regions with the poorest and least developed livestock sub-sector of agriculture in the world.

\section{REFERENCES}

Abubakar, S. M. (2004). The impact of conflict on the economy: The case of Plateau state of Nigeria. Retrieve from http://www.odi.org.uk/speeches/nigeria2004/AS\%20mohammed\%web\%20paper.pdf on 27 August 2007.

Ansah, T., Dzoabge, G. S. K., Djang-Fordjour, K. T., Agbolosu, A. A. and Weseh, A. (2006). The role of churches in the sustainability of livestock production in the Northern region. The Savannah Farmer. A magazine on Sustainable Agriculture. The Association of Church Development Project (ACDEP) of Ghana. 35pp

Avornyo, F. K., Otchere, E. O. and Mbii, P. (2007). A baseline survey of small ruminants project communities in the Northern region. In: Bruce, J., Karbo, N., Clottey, V., Adongo, F., Alebbikiya, M. and Asobayire, M. (eds.). Innovative Participatory Research and Development: the farmer at centre stage. Proceedings of the National Conference on Participatory Agricultural Research and Development. May 9- 13, 2007. 316 pp.

Bacho, Z. L. F. and Abdul-Kadir, M. S. (2007). Artificial creation of states and enduring conflicts in Africa: legacies of the "indirect rule" policy in the Northern parts of Ghana and Nigeria. Ghana Journal of Development Studies. 4(1), $13-27$

Brock-Utne, B. (2001). Indigenous conflict resolution in Africa. A draft presented to the week-end seminar on indigenous solutions to conflicts held at the University of Oslo, Institute for Educational Research $23-24$, February 2001. Retrieved from http://africavenir.com/publications/occasionalpapers/BrockUtneTradConflictResolution.pdf on 25 August 2007.

Food and Agricultural Organization of the United Nations (FAO) (2004). The state of food and agriculture: 2003 - 04, FAO, Rome 2004. 


\section{Journal Of Agriculture and Social Research (JASR) Vol. 8, No.1, 2008}

Ghana Poverty Reduction Strategy Paper (GPRS, 2003-2005) (2003). An agenda for growth and prosperity. Volume 1: Analysis and policy statement, February, 19 2003. Retrieved from http://poverty2.forumone.com/files/Ghana_PRSP.pdf on 17 September, 2007.

Jösson, J. (2007). The overwhelming Minority: Traditional Leadership and ethnic conflicts in Ghana's Northern region. Centre for Research on Inequality, human Security and Ethnicity (CRISE). Department of International Development, University of Oxford. Working paper No. 30. Retrieved from http://www.crise.ox.ac.uk/pubs/workingpaper30.pdf on 8 September 2007.

Karbo, N. and Bruce, J. (2000). The contribution of livestock production to food security in Northern Ghana. CIDA (Canadian International Development Agency) food security programme. A report submitted to CIDA by the Animal Research Institute of the Council for Scientific and Industrial Research, Tamale, Ghana, Pp. 3-11.

Kusimi, J., Fobil, J., Atugba, R., Erawoc, I. and Oduro, F. (2006). Conflicts in Northern Ghana-A mirror of answers to sub-regional stability and security questions. *Asteriskos. Journal of international and peace studies 1/2: 209. Retrieved from http://www.igesip.org on 10 September 2007.

Linde, V. A. and Naylor, R. (1998). From conflict to conciliation: NGOs consortium for peace in Northern Ghana. A report for the Northern Ghana Inter-NGO consortium and Oxfam, Great Britain. 99 pp.

Mahama, I. (2003). Ethnic conflicts in Northern Ghana. Cyber systems press, Tamale, Ghana. $261 \mathrm{pp}$

Messer, E. and Cohen, M. J. (2004). Breaking the links between conflict and hunger in Africa. Paper presented at an international conference ("Assuring food and nutrition security in Africa by 2020") organized by the Vision 2020 Initiative of the Food Policy and Research Institute (IFPRI) in Uganda, Kampala. April 1-3, 2004. Conference brief No. 10. Retrieved from http://www.ifpri.org/pubs/ib/ib26.pdf on 30 August 2007.

MoFA (Ministry of Food and Agriculture) (1994). A report on tour of conflict area of the Northern region by the minister of state for the Ministry of Food and Agriculture. June, 20-25 ${ }^{\text {th }} 1995$

NHPC (National Housing and Population Census) (2000). National population and housing census. Summary of reports of final results. Ghana Statistical Service, Accra, Ghana

Otchere, E. O., Zuri, M. B. T., Karbo, N., Dei, H. K. and Djang-Fordjour, K. T.

(2007). Management and performance of West African Short Horn cattle in the SabobaChereponi district in the Northern region. Ghanaian Journal of Animal Science. 2\&3 (1), $145-152$.

Octchere, E. O., Karbo, N., Bruce, J., Aning, K .G., Aboe, P., Clotty, V. A. and Asare, G. (1997). Livestock systems diagnostic survey: Saboba-Chereponi district of the Northern region. A technical report. Animal Research Institute of the Council for Scientific and Industrial Research, Ghana. December, 1997. 73pp.

SPLP (Strategic Plan for Livestock Production in the northern region) (1996). A report submitted to the Ministry of Food and Agriculture (MoFA) for the Development of National policy on 
Journal Of Agriculture and Social Research (JASR) Vol. 8, No.1, 2008

livestock production in Ghana. Ministry of Food and Agriculture, Government of Ghana. April, 1996. 17pp

Talton, B. A. (2003). The past and present in Ghana's Ethnic Conflicts: British Colonial Policy and Komkomba Agency, 1930-1951. Journal of Asian and African Studies 30(2-3), 192-210. 